\title{
The Institutional and Policy Environment and the Quest for Industrialization in Nigeria
}

\author{
${ }^{*}$ Martins Iyoboyi ${ }^{1}$, Olarinde Muftau 0., ${ }^{2}$ Abdulsalam S. Ademola ${ }^{1}$ \\ ${ }^{1}$ Federal University, Dutsin-ma, Katsina, Nigeria \\ ${ }^{2}$ Usmanu Danfodiyo University, Sokoto, Nigeria \\ *miyoboyi@fudutsinma.edu.ng
}

\begin{abstract}
The paper empirically investigates the impact of the institutional and policy environment on Nigeria's industrialization, using annual data for the period 1981 to 2013. The institutional environment was proxied by quality of service delivery while government expenditure as a percentage of GDP and real exchange rate were used to reflect the policy environment. Foreign direct investment as percentage of GDP was employed to reflect technological transfer and diffusion. Using the technique of cointegration, a long run relationship was found between industrialization and associated variables. Government expenditure was found to be positively related to industrialization and statistically significant in the long and short run. In the short run, real exchange rate is positively related to industrialization and statistically significant, while a negative and statistically significant relationship was found in the long run. In the long and short run, technological transfer indicates a negative relationship with industrialization. Quality of service delivery was found to influence industrialization positively and significantly in the long and short run. A bilateral causality was found between industrialization and the associated variables. Based on the empirical findings, it is concluded that the institutional and policy environments are critical to industrialization in Nigeria and that pragmatic efforts should be made to initiate and implement policies that promote industrial growth, while enhancing the quality of institutions.
\end{abstract}

Keywords: Cointegration, Industrialization, Institutions, Policy

\section{Introduction and Literature}

Industrialization is the deliberate and sustained application and combination of suitable technology, management techniques and other resources which move an economy from a traditional mode to an efficient system of large-scale production. This enables a country to optimize its factor endowments and to depend less on foreign supply of finished goods or raw materials for its economic growth, development and sustenance. It also helps a country to reduce volatilities originating predominantly from external shocks. Consequently, a robust competitive industrial sector is germane which broadens the productive and export base of the economy, reduces unemployment, and stems rural-urban drift, in addition to promoting reduced poverty, all of which stimulate growth and sustainable economic development (Freeman, 1976). Achieving an inclusive and sustainable growth is hinged on the level of industrialization which, among others, can fasttrack structural transformation and diversification of an economy. The quest to transform the Nigerian economy through industrial development has not been successful despite the country's abundant human and non-human endowments (IMF, 2010; World Bank, 2012). Particularly, it seems to have defied all industrialization strategies. The policy reforms introduced in Africa in general and Nigeria in particular in the 1980s tended to rely on the premise that once the external balance is stabilized (achievable mainly from macroeconomic stability), all that is required is the removal of government distortions to "get the prices right" in order to reallocate factors towards high productivity industries (Chukwuma and Aldo, 2013). This cannot be said to be the case with Nigeria.

Many countries have however enjoyed unprecedented improvements in external balances alongside continued decrease in industrial production. The dismal state of industrial sector creates a cycle of perpetual dependency, leaving the countries reliant on the export of raw materials and consequently exposed to exogenous shocks. Without a sustainable industrial development which can add value to raw materials and create jobs, it is likely that a country would remain vulnerable to the dictates and manipulations of prices of their primary products by foreign countries (Umo, 2012). Attempts at promoting industrialization and by 
extension economic diversification and structural transformation in the past by Nigeria necessitated the introduction of the Import Substitution Industrialization (ISI) strategy and Export Promotion Industrialization (EPI) between 1962 and 1968, aimed at encouraging technological development and foreign exchange savings as well as reducing reliance on foreign goods. It also involved massive direct government investment in industrial projects and infrastructure. However, the policy could not be sustained due largely to weak technological base, low level of diversification, over dependence of industrial activities on imported inputs, coupled with high level of inflation and interest rates. Consequently, the collapse of the world oil market in the early 1980s resulted in drastic decline in foreign exchange needed to procure required industrial inputs and spare parts. The import dependency by the industrial sector became unsustainable. Subsequently, various economic reform programmed such as the Structural Adjustment Programme (SAP), the National Economic Empowerment Development Strategy (NEEDs), and the Vision 20:2020 were introduced to salvage the pathetic industrial sector between 1986 and 2008, with an increase in industrial and manufacturing share of output of $30-50 \%$ and $15-30 \%$ respectively from their existing share of $23.8 \%$ and $4 \%$ projected. The policy response had been expansionary monetary policy through monetary policy rate cuts, reduction in cash reserve ratio and liquidity ratios, aimed at encouraging private investment. The deregulation of the economy was also encouraged with a view to attracting foreign direct investment in the sector through a competitively-determined exchange rate.

In Nigeria, stylized facts indicate that improved macroeconomic stability seems to have declining impact on the rate of industrialization. During the period under review, the country experienced some level of macroeconomic stability with GDP per capita growth rate of 5.05\% which was above the sub-Saharan average and a decline in external debt stocks from $13.91 \%$ in 2008 to $11.41 \%$ in 2011 (Word Bank, 2013). The manufacturing sub-sector however did not reflect this growing trajectory. Whereas its contribution to GDP was as much as $7.3 \%$ in 1993, it fell to $6.2 \%$ and $5.9 \%$ in 1998 and 2001 respectively. The sector experienced a marginal improvement of $6.5 \%$ in 2004 but fell to $4.4 \%$ in 2006 and a further dip to $2.6 \%$ in 2010 (Mordi et al., 2010; UNECA, 2012). Data on manufacturing value added among developing countries indicates a very low development of the manufacturing sector in Nigeria. In 2010, the country recorded 1.97 billion US Dollars as against valued added figure of 4.35, 62.10 and 280.65 billion US Dollars recorded by Cote D'lvoire, Malaysia, and Brazil respectively (World Bank, 2013). Apart from this, the country also enjoyed relatively favourable terms of trade along with falling rate of inflation which is expected to impact positively on level of capital investment, ceteris paribus. An x-ray of the export composition of the country reveals a disappointing situation of its level of structural transformation. Crude oil export still dominates the total export composition while manufacturing and agricultural export remain at a very low level. It should be noted that value added required for the agricultural output to attract foreign demand could not be made possible without improvement in technology through industrial development, hence the disappointing performance of agricultural export by a sector that employed a large proportion of the population.

The above scenario logically leads to the need to question the role of macroeconomic policies in supporting and sustaining a process of industrialization and diversification. Specifically, it is pertinent to ask whether the macroeconomic environment, in addition to various reforms undertaken in Nigeria is sufficient to serve as a springboard for the needed industrialization and diversification of the economy. Fischer (1993) listed five conditions, which together imply that a macroeconomic policy environment is conducive to sustainable economic diversification and growth. These are a low and predictable inflation rate, an appropriate real interest rate, a stable and sustainable fiscal policy, a competitive and predictable real exchange rate and a viable balance of payments. Thus, a sound macroeconomic policy among other factors is imperative to the achievement of industrialisation and crucial for diversification. We extend the Fischer (1993) conditions by adding the role of the institutional environment, since developing countries are particularly plagued by weak institutions.

Previous studies were mainly devoted to the relationship between policy volatility and economic diversification and industrialization. Non-volatile economic policy environment has been found to be germane to a sustainable structural diversification and industrial development (Soderbom and Francis, 2002; Ndiyo and Ebong, 2003; Michael and Babasanmi, 2004; Chukwuma and Aldo, 2013; García-Belenguer and Santos, 2013; Ebong et al., 2014). On Nigeria, Agba (2004) affirms that a sound monetary policy via viable interest rate regimes and incentives which attract greater savings are a pre-requisite for industrial 
development. Odior (2005) investigates the impact of macroeconomic factors on manufacturing productivity in Nigeria for the period 1975-2011. Credit to the manufacturing sector and foreign direct investment were found to be positively related to manufacturing productivity, while broad money supply (M2) has lower impact. Price instability (proxied by consumer price index) was found to negatively impact manufacturing sector performance. On the impact of interest rate on industrialisation, Ubi et al. (2012), using vector error correction mechanism, found that the value of interest rate and its one year lagged value are contemporaneously negative and are all statistically insignificant at 5 per cent level. Michael and Babasanmi (2004) conclude that interest rate spread and government deficit financing have negative impact on the growth of manufacturing sub-sector in Nigeria. Adenikinju (2005) provides a strong argument on the importance of energy supply to the overall industrial development of Nigeria. The poor supply of electricity in the country imposes significant cost on the industrial sector of the economy. In line with this view, Ndebbio (2006) argues that electricity supply drives industrialization process, arguing that one important indicator whether a country is industrialized or not is the megawatt of electricity consumed, so that a country's electricity consumption per-capita in kilowatt hours is proportional to the state of industrialization of that country. This viewed is supported by Udah (2010), who investigates the causal and long-run relationship between electricity supply, industrialization and economic development in Nigeria from 1970-2008, and finds a feedback causal relationship between GDP per capita and electricity supply.

A number of studies have been conducted to examine the role of the institutional environment on industrialization. Weder (1998) investigates the relationship between investment climate (an institutional factor) and industrial productivity on 21 Sub-Saharan African countries. The institutional factors employed were qualitative information on annual ratings of the following indicators: quality of bureaucracy, the rule of law, policy surprises, extent of availability of information on new rules and degree to which business can participate in making new rules. Also included in the cross sectional analysis are predictability of judiciary enforcement, theft and crime, security of property rights, frequency of corruption as well as uncertainty of corruption and corruption perceived as an obstacle to business. The study concludes that such factors as predictability of judiciary enforcement, theft and crime, security of property rights and uncertainty of corruption are significant constraints to industrial productivity. Only a handful of studies have been devoted to how institutions impact industrialization in Nigeria. Bakare (2013) examined the linkage between the business environment (investment climate) and the performances of industrial sector in Nigeria. A negative relationship between investment climate and the performances of industrial sector in Nigeria was found, while corruption and political instability seriously constrain its performance. In addition, poor infrastructure and macroeconomic instability were found to play a significant role in undermining the industrial sector. Osabuohien et al. (2013), on the importance of institutions in the development and sustenance of some important segments (finance, education, technology, industry and trade) on Nigeria advocates the need for the incorporation of Nigeria's traditional norms and values and the commitment of the state to building formidable institutions for sustainable growth.

This paper contributes to existing empirical literature by investigating the influence of the institutional and policy environment on the quest for industrialization in Nigeria. One major lacuna in previous empirical studies on Nigeria is the scanty assessment of the impact of the institutional environment on her drive towards industrialization. The country is not in want of policies and reforms and all economic prescriptions to arrest identified structural weaknesses over the years have been largely unsuccessful. It is likely that the missing link in the country's quest for industrialization is the institutional environment, which may provide the mechanism through which policies and reforms transmit to industrial development. This provides the intuition for the present study. One noticeable gap in previous studies is that although the scholars used time series aggregate data, the possibility of structural breaks in the series was not considered while testing the relationships, the neglect of which might have serious consequences on the validity of inferences. An attempt was made to fill this gap in the study. Whereas previous empirical papers on Nigeria examined the impact of policy and institutions on industrial growth separately, they are combined in the present study in a single framework and their joint impact on the rate of industrial growth investigated. From the foregoing, the paper examines the institutional and policy environment and their impact on the quest for industrialization in Nigeria. Following the introduction, the rest of the paper has the following structure. Methodology is covered in Section 2. The empirical results are presented and discussed in Section 3. The paper is concluded in Section 4. 


\section{Methodology}

Dataset and description of Variables: Annual data for the period 1981 to 2013 were used in the study. An extensive examination of the literature indicates the imperative of including as many variables as possible as usefully capture the determinants of industrialization. Consequently, industrialization, defined broadly as encompassing manufacturing share of output, is a function of policy, technological capability and institutions. Manufacturing has been found to typically lead the way and grow faster than other sectors of the economy when there is acceleration in overall growth (Syrquin, 1986). Consequently, industrialization was proxied by manufacturing value added as percentage of GDP. Our measure of fiscal policy is government expenditure as a percentage of GDP. Monetary policy was captured by real exchange rates, considered more appropriate in the context of the dependent variable than interest rate, due to its relative importance for international trade competitiveness.

Real exchange rate (REXCR) is defined as:

$$
R E X C R=\frac{E \cdot P_{f}}{P_{d}}
$$

Where $\mathrm{E}$ is the nominal exchange rate, $\mathrm{P}_{\mathrm{f}}$ the foreign price level and $\mathrm{P}_{\mathrm{d}}$ the domestic price level. The consumer price indices for the United States and Nigeria were used as the foreign and domestic price levels respectively.

Technological change is imperative to industrialization. Research and development (R\&D) activities are drivers of technological change. R\&D activities in developing countries are limited and fraught with paucity of data. However, one source of growth for industrialization is international technology diffusion, fostered by international trade and foreign direct investment, and are thus channels of technology transfer and diffusion. Our measure of technological capability is therefore net inflows of foreign direct investment as percentage of GDP. For the institutional environment we used a second generation governance indicator, i.e. the quality of service delivery, proxied by electricity consumption (in kilowatts) per capita. Using second generation governance indicators has three vital advantages: (1) they are politically acceptable; (2) they are appropriate for rigorous quantitative analyses; and, (3) they are operationally relevant. The data are from the World Development Indicators (World Bank, 2014) and the Statistical Bulletin of the Central Bank of Nigeria (CBN, 2014). The choice of the quality of service delivery used in the study is underscored on two major reasons. First, it measures the effectiveness and capacity of social institutions, and consequently the effectiveness of government programmes and how well people are satisfied with public policy. In the light of this, the institutional environment in terms of capacity to deliver basic public services is critical to the efforts made by a country to achieve its development goals. Second, adequate electricity supply and consumption is imperative to growth as found in previous empirical investigations on Nigeria (Ndebbio, 2006; Udah, 2010).

It needs to be emphasised that investments have long been recognized as critical to growth. However, because they are endogenous to the shares of manufacturing and essentially reflects the same intuition as the dependent variable in the study, it was omitted and instead variables that would drive them in the first place such as macroeconomic policies (as reflected by fiscal, monetary and trade, previously described), human capital and the quality of institutions were considered appropriate. Due to the non-availability of data on the average years of schooling for the population of above 15 years of age, the human capital variable was omitted. The descriptive statistics for the variables employed in the investigation are provided in Table $1 \mathrm{~A}$ and the trend in Figure 1A of the Appendix. To remove heteroscedasticity, all the variables were transformed into natural logs before estimation.

Model Specification and Estimation Procedure: On the basis of theory, the following is a dynamic specification:

$$
I N D_{t}=\beta_{0}+\beta_{i} X_{i}+\sum_{i=-p}^{p} \delta_{i} \Delta X_{t-i}+\varepsilon_{t}
$$

Where $\beta_{0}$ and $\delta_{i}, \delta_{p}$ are parameters to be estimated and $\varepsilon_{\mathrm{t}}$ is the disturbance term assumed to be normally and identically distributed. $X$ is a vector of regressors as defined previously, $\Delta$ is the lag operator. 
Consequently, the regressors and its associated explanatory variables are indicated in the following specification:

$$
I N D_{t}=\beta_{0}+\beta_{1} G E+\beta_{2} R E X C R+\beta_{3} T E C H T R A N S+\beta_{4} Q S E R V D E L+\varepsilon_{t}
$$

Where IND represents industrialization; GE is government expenditure; REXCR stands for real exchange rate; TECHTRANS is technological transfer; and QSERVDEL is reflective of quality of service delivery.

All the variables were investigated for their stochastic properties. Three unit roots tests, namely the Augmented Dickey-Fuller (ADF), Phillips-Perron (PP) and Kwiatkowski-Phillips-Schmidt-Shin (KPSS) tests were implemented. However, traditional tests for unit-roots such as the ADF and PP are known to have low power in the presence of structural breaks, and a tendency to "discover" unit roots that are not actually present. Therefore, we considered the Zivot and Andrews (1992) and Perron (1997) frameworks to explore the presence or otherwise of unit root when there are breaks in the series. Zivot and Andrews (1992) tests allow for exogenous single structural break in the intercept (Model A), and both the intercept and trend (Model C) of the series, given by the following specifications:

$\begin{array}{ll}\text { Model A: } & y_{t}=\hat{\mu}^{A}+\hat{\theta}^{A} D U_{t}(\hat{\lambda})+\hat{\beta}^{A} t+\hat{\alpha}^{A} y_{t-1}+\sum_{j=1}^{k} \hat{c}_{j}^{A} \Delta y_{t-j}+\hat{e}_{t} \\ \text { Model C: } & y_{t}=\hat{\mu}^{C}+\hat{\theta}^{C} D U_{t}(\hat{\lambda})+\hat{\beta}^{C} t+\hat{\gamma}^{C} D T_{t}^{*}(\hat{\lambda})+\hat{\alpha}^{C} y_{t-1}+\sum_{j=1}^{k} \hat{c}_{j}^{C} \Delta y_{t-j}+\hat{e}_{t}\end{array}$

where, $D U_{t}(\lambda)=1$ if $\mathrm{t}>T \lambda, 0$ otherwise; $D T_{t}^{*}(\lambda)=t-T \lambda$ if $t>T \lambda, 0$ otherwise.

Perron (1997) developed the following frameworks to test for a unit root in the presence of a structural break:

Innovational Outlier Model allowing one time change in intercept only (IO1):

$y_{t}=\mu+\theta D U_{t}+\beta_{t}+\delta D\left(T_{b}\right)_{t}+\alpha y_{t-1}+\sum_{i=1}^{k} c_{i} \Delta y_{t-i}+e_{t}$

Innovational Outlier Model allowing one time change in both intercept and slope (IO2):

$y_{t}=\mu+\theta D U_{t}+\beta_{t}+\gamma D T_{t}+\delta D\left(T_{b}\right)_{t}+\alpha y_{t-1}+\sum_{i=1}^{k} c_{i} \Delta y_{t-i}+e_{t}$

Perron (1989) views most time series as capable of being sufficiently modelled either by Model A or Model C. Sen (2003) maintains that applying Model A leads to a substantial power loss if the break actually occurs in Model C, whereas if the break occurs in Model A but Model C is used, there is a minimal loss of power. Model $\mathrm{C}$ was applied in the present study. Because structural breaks in the series can substantially distort standard inference procedures for cointegration, we accounted for possible breaks in the data before inference on cointegration was made, by following the approach developed by Johansen, Mosconi and Nielsen (Johansen et al., 2000), a procedure that extends the standard vector error correction model (VECM) which incorporates a number of dummy variables to reflect the possible exogenous breaks in the levels and trends of the deterministic components of a vector-valued stochastic process. It derives the asymptotic distribution of the likelihood ratio (LR) or trace statistic for cointegration and generates critical or p-values with the possible breaks, using the response surface method. To implement the cointegration test, we first fit an unrestricted VAR model and tested for the lag length, autocorrelations, heteroscedasticity and stability, all of which were satisfactory. The result of the lag length selection criteria, residual serial correlation and heteroscedasticity and stability are not reported to conserve space but are available on request. Equation (3) was estimated by OLS by first including 6 lags, and deploying Hendry's (1986) General to Specific (GETS) methodology to generate the parsimonious results.

\section{Results and Discussion}

Empirical Results: The results of pre-estimation diagnostics involving tests of stationarity and cointegraton are presented in Tables 1B, 1C and 1D of the Appendix. In Table 1B, three traditional tests which do not consider structural breaks are presented. For the ADF, all the variables are stationary at first difference. The same can be said about the PP test, except for service delivery which tends to be stationary at level. For the KPSS test, evidence is in favour of stationarity at first difference for all the variables except government 
expenditure. On the whole, it is plausible to conclude that the variables used in the study have a unit root. The results of stationary tests in the presence of structural breaks are presented in Table 1C. In Panel A, both the Zivot-Andrews and Perron tests are substantially similar. Whereas the null hypothesis of a structural break in intercept is accepted for IND, GE, REXCR and TECHTRANS in the Zivot-Andrews test, this is also true for the Perron test. The break dates are also relatively similar.

The results of the test with a structural break in the intercept and trend in Panel B indicate that there are structural breaks in GE, REXCR and TECHTRANS with 1993 as the exogenous break date. The null hypothesis is not rejected for all the variables in the Perron test results except for QSERVDEL. In the study, the ZivotAndrews test results for breaks in both intercept and trend (Model C in Panel B) were used. Consequently, the test of cointegration was conducted with appropriate intervention dummies incorporated to account for the breaks reported in the Zivot-Andrews results. The cointegration test results presented in Table 1D of the Appendix suggest that the null hypothesis of no cointegration is rejected, as indicated by the Johansen et al. (2000) trace test statistics. Using the conventional 5\% and 1\% levels, there are three cointegrating vectors. The presence of cointegration necessitates a short-run framework reflected in an error correction model. The empirical results of the institutional and policy environment and their impact on the quest for industrialization in Nigeria are presented in Table 1.

Table 1: Estimated Regression Results

Panel A: Long-run estimates

Period: 1981-2013(Dependent Variable: IND)

\begin{tabular}{llll}
\hline Variable & Coefficient & Std. Error & t-Statistic \\
\hline INTERCEP TERM & -0.672752 & 1.072381 & -0.627344 \\
IND $_{\mathrm{t}-1}$ & $0.499298^{*}$ & 0.115465 & 4.324218 \\
$\mathrm{GE}_{\mathrm{t}-1}$ & & & \\
$\mathrm{REXCR}^{\text {TECTRANS }}$ & $0.251949^{* * *}$ & 0.136427 & 1.846768 \\
QSERVDEL $_{\mathrm{t}-6}$ & $-0.168115^{* * *}$ & 0.092425 & -1.818937 \\
Diagnostics & $-0.321195^{*}$ & 0.079741 & -4.027954 \\
& $0.418013^{* * *}$ & 0.230702 & 1.811919
\end{tabular}

Diagnostics

$\mathrm{R}^{2}$ : 0.89; Adjusted R²: 0.85; SER: 0.155264; DW: 2.29; F-statistic: 19.16860 (0.000000); $\mathrm{BG}$ [ $\left.\chi^{2}, 1\right]$ : 1.310609

(0.2523); BG [ $\left.\chi^{2}, 2\right]: 3.485221$ (0.1751); JB: 0.147277 (0.929008); ARCH [ $\left.\chi^{2}, 1\right]$ : 0.073716 (0.7860); ARCH:

$\left[\chi^{2}, 2\right] 1.131865$ (0.5678); RESET (T-stat.): 1.190762 (0.2501)

Panel B: Short-run estimates

Period: 1981-2013(Dependent Variable: $\Delta$ IND)

\begin{tabular}{llll}
\hline Variable & Coefficient & Std. Error & t-Statistic \\
\hline INTERCEP TERM & $-0.617445^{* *}$ & 0.244131 & -2.529152 \\
$\Delta \mathrm{GE}_{\mathrm{t}-3}$ & $0.226626^{* * *}$ & 0.129094 & 1.755507 \\
$\Delta$ REXCR $_{\mathrm{t}-2}$ & $0.137257^{* *}$ & 0.067007 & 2.048392 \\
$\Delta$ TECTRANS $^{*}$ & $-0.199187^{* *}$ & 0.084274 & -2.363554 \\
QSERVDEL $_{\mathrm{t}-3}$ & $0.370346^{* *}$ & 0.137469 & 2.097424 \\
CCM $_{\mathrm{t}-1}$ & $-0.470509^{* *}$ & 0.195994 & -2.400631 \\
\hline
\end{tabular}

Diagnostics

$\mathrm{R}^{2}$ : 0.60; Adjusted R²: 0.41; SER: 0.185819; DW: 1.92; F-statistic: 3.137347 (0.022628); BG [ $\left.\chi^{2}, 1\right]$ : 0.071429

(0.7893); BG [ $\left.\chi^{2}, 2\right]: 3.741424$ (0.1540); JB: 2.376009 (0.304829); ARCH [ $\left.\chi^{2}, 1\right]$ : 0.640475 (0.4235); ARCH: $\left[\chi^{2}, 2\right] 0.809995(0.6670)$

, $* *$ and ${ }^{* * *}$ indicate statistical significance at the $1 \%, 5 \%$ and $10 \%$ levels respectively. Probability value is in parenthesis. SER: Standard error of regression; DW: Durbin-Watson test for autocorrelation; JB: Jarque-Bera test for normality of residuals; BG: Breusch-Godfrey test for autocorrelation; ARCH: Engle's test for conditional heteroskedasticity. RESET: Residual Error Specification Test.

Source: Authors' computations. 
Discussion: The coefficients of government expenditure are positively signed in the long and short run, and statistically significant at the $10 \%$ level, indicating that a rise in government spending is associated with an increase in the rate of growth in industrialization. From the results, it can be inferred that for the Nigerian economy under the period of investigation, government expenditure is an important and significant determinant of industrialization. In other words, government spending significantly determines the impetus of industrialization for the Nigerian economy. A rise in government expenditure by $1 \%$ is associated with $0.25 \%$ increase in the rate of industrialization in the long run and $0.25 \%$ increase in the short run. Overall, the empirical results are in favour of a statistically significant impact of government spending on Nigeria's drive towards industrialization. The results are hardly surprising, given that for a developing economy, the role of government in providing huge capital and the provision of infrastructure is critical to leverage a relatively weak private sector.

In the short run, real exchange rate is positively related to industrialization and statistically significant at the $5 \%$ level. A negative and statistically significant relationship at the $5 \%$ level is found in the long run. It needs to be noted that there is an appreciation of the real exchange rate when it increases and depreciation when it decreases. The results suggest that devaluation tends to support the growth of the industrial sector in Nigeria in the short run, while in the long run, the rate of the country's industrial growth is reduced. Consequently, devaluation which has tended to underpin policy measures in Nigeria during the period of investigation has not been helpful in promoting industrial growth. The reasons for this are not far-fetched. One of the driving forces for structural change is the change in domestic and international demand, which is largely influenced by domestic prices. Devaluation does stimulate export trade on the basis that goods are produced internally and are ready for sale. In an environment where production is hampered largely by constraints ranging from low power supply, relatively high interest rate, to dependence on imports for raw materials and inflationary trends, the impact of devaluation on growth in the industrial sector cannot be felt positively. In essence, it is bad policy to devalue in the name of industrial promotion in an environment which is largely hostile to mass production. If domestic production is not initially stimulated to the extent that mass production calls for the imperatives of new markets, devaluation can only worsen the state of a country's industrial development.

A cursory examination of Nigeria's trade pattern over the years indicates that the country has been largely import dependent and even so for industrial inputs. Devaluation can only worsen a situation when an economy depends on the import of chemicals, machines and other production inputs to improve its industrial development. In such a situation, the Nigerian industrial sector finds it increasingly difficult to face stiff external competition, and cannot be said to reflect under an open trade regime, any specialization. It is thus an open question and remains debatable whether Nigeria specializes in the production of any commodities for which the country has a comparative advantage and import commodities which are relatively expensive to produce domestically. What is not in doubt from the empirical results is that exchange rate management has been poor and has not been successful in promoting the rate of industrial growth in Nigeria. Although exchange rate devaluation is expected to create opportunities such as the facilitation of foreign direct investment, export of local raw materials and the importation of necessary inputs into the industrial process, this is made possible only in an environment which is supportive to industrial growth. As long as an economy is import-dependent, it is not likely that the pace of industrialization will be improved, due largely to the difficulty and constraints imposed by currency depreciation on local industrial outlets. In the long run however, devaluation can be one way of improving growth, as the imperatives of new outlets for domestic expansion and the competitive international environment would justify measures that make it relatively more difficult to import and easier to export commodities that have been produced in large quantity. It is thus plausible to have a positive relationship between real exchange rate and industrialization.

A policy of devaluation tends to harm the structure of the Nigerian economy which does not support a strong industrial base. Efforts to industrialize through implementation of macroeconomic policy aimed at incorporating imported technical means of production are not likely to work, since devaluation makes imports costlier. Besides, there is the problem of dualism, some disconnect between the rural economy (exemplified by agriculture) and the industrial sector (the modern economy), coupled with an increasingly inefficient and poorly diversified industrial structure, all of which produce a certain tendency in the system that makes macroeconomic policy vulnerable to external imbalances. This lack of diversified industrial production base has resulted in a comparative disadvantage, making the country's term of trade volatile over 
the years. Moreover, the country is highly dependent on a single export commodity (i.e. crude oil), a situation that tends to increase macroeconomic policy volatility, in line with the argument by Papageorgou and Spatafora (2012). Under these conditions, devaluation is least likely to promote the growth of industrialization.

In the long and short run, the coefficients of technological transfer (proxied by foreign direct investment) indicate a negative relationship with industrialization, and are statistically significant at the $1 \%$ and $5 \%$ levels respectively. Consequently, foreign direct investment does not seem to promote the needed technological transfer which would induce faster rate of industrialization. The postulation of theory is that the degree of economic openness (which fosters higher FDI inflows) can have an important influence on its pattern of specialization and industrialization. If countries are open to trade, they should, according to Heckscher-Ohlin theory, specialize in the production of commodities in which they have a comparative advantage. In labourabundant countries, trade liberalization would tend to shift production from capital-intensive import substitutes towards labour-intensive exportables. Due to this change, domestic inequality in those countries is expected to decline because of the increased demand for labour, whereas inequality would increase in countries with an abundant endowment of capital. Liberalization of foreign direct investment can also decrease inequality in capital-importing countries, but that depends in part on the degree of skill-bias of technologies employed by foreign invested firms. However, developing countries' terms of trade would decline if their structural change would make them specialize in primary commodities and resource intensive industries, sectors for which developing countries have comparative advantages (Prebisch, 1950; Singer, 1950). This has been the case of Nigeria. The results is in resonance with those found by Cimoli and Katz (2003), who review the industrial history of Latin America and conclude that liberalization and openness in the 1980s destroyed the progress achieved by inward-oriented policies from the 1930s to the 1980s especially in technology intensive sectors. What is clear from the estimated results is that technological transfer via foreign direct investment is far from being achieved for the Nigerian economy, resulting in a lower rate of industrialization. It needs to be stated that part of the theoretical rationale for improved foreign direct investment inflow is globalization, with its prong of liberalization. As found by Aluko et al. (2004), globalization has strong adverse effects on the Nigerian manufacturing sector with particular reference to textile firms, with serious constraints on capacity utilization, implying that manufacturing firms in the country do not appear to be fully prepared for the challenges of globalization, a finding that is amply supported by the results of the present investigation.

The coefficients of quality of service delivery indicate a statistically significant positive relationship with the rate of industrialization in both the long and short run. Importantly, a $1 \%$ rise in the quality of service delivery (embodied in higher electricity consumption) is associated with $0.42 \%$ and 0.37 increases in the rates of industrial growth in the long and short run respectively. Consequently, quality of service delivery is key to faster industrial growth. Empirical evidence is in favour of improved industrial development where there is a supportive environment of cost reductions in power, transport and communications, which are often provided through public investment (Blejer and Khan, 1984; Greene and Villanueva, 1991). Thus, the institutional environment is critical to industrialization, while the quality of electricity provided is especially crucial for Nigeria, resonating previous empirical findings (Adenikinju, 2005; Ndebbio, 2006; Udah, 2010). The error correction model (ECM) coefficient is negative and statistically significant at the 5 percent level. A deviation in industrial growth from equilibrium is corrected by about 47 percent the following year. The ECM value further lends empirical credence to the test results of cointegration. In both the long and short run estimated results, the diagnostic statistics are quite satisfactory. The adjusted $\mathrm{R}^{2}$, indicating the overall fit of the estimated model shows that the independent variables used in the model jointly accounted for 85 percent variation in the long-run. In the short-run, about $41 \%$ variation in industrial growth is accounted for by changes in the explanatory variables used. In addition, the null hypothesis of autocorrelation in the residuals is rejected in the estimated model as indicated by the BG and DW statistics respectively. There is no evidence of heteroscedasticity as indicated by the ARCH tests. The residual error specification test (RESET) indicates that the long run estimated model does not suffer from misspecification.

Causality Test Results: The causality test results implemented in the error correction mechanism are presented in Table 1E of the Appendix. From the estimated results, the null hypothesis of Granger noncausality is rejected for all the variables in the estimated model. It can be concluded that each of the variables, 
namely industrialization (IND), government expenditure (GE), technological transfer (TECTRANS), service delivery (SERVDEL) and real exchange rate (REXCR) Granger-causes other variables in the system. Consequently, there is bilateral causality among the variables. The implication of the results is that each of the variables can be predicted by its present value and the past values of other variables.

\section{Conclusion}

In this paper, the impact of the institutional and policy environments on Nigeria's industrialization is investigated, using annual data for the period 1981 to 2013. The study utilized the technique of cointegration to explore the short and long run dynamics among the variables. Quality of service delivery was used to proxy the institutional environment, while government expenditure and exchange rate were employed to reflect the policy environment. Foreign direct investment was used to capture the degree of technological transfer. A long run relationship was found between industrialization and associated variables. Government expenditure was found to be positively associated with industrialization. In both cases, government expenditure is a statistically significant variable determining the rate of industrial growth in Nigeria. While real exchange rate exerts a positive impact on the rate of industrialization in the long run, the reverse was found in the short run. Technological transfer, reflected in foreign direct investment, was found to be inversely related to industrialization and statistically significant in both the long and short run. Quality of service delivery, reflecting the institutional environment was found to be positively related to and a statistically significant determinant of industrialization in the long and short run.

Certain policy implications are evident from the study. The empirical results indicate that higher government spending is associated with higher rate of industrial growth. Government expenditure should be aligned to the real sector of the economy. However, spending should be used with discretion on infrastructure that promotes industrial growth. Devaluation is not likely to promote the country's industrial growth at a time when the country is highly import-dependent. The empirical results indicate that higher real exchange rate (devaluation) is associated with lower rate of industrial growth in the short run. Thus, devaluation tends to be bad policy when the economy is not yet poised to compete in the international market. The major lesson is that devaluation is a practical question of the state of affairs of a country. Foreign direct investment does not seem to promote the needed technological transfer which would induce faster rate of industrialization. Local technologies are required if the country is to facilitate its rate of industrialization. Better quality of service delivery is central to industrial growth. The poor nature of electricity supply in Nigeria should be addressed, as it imposes significant cost on the industrial sector of the economy. Adequate electricity supply is a key driver of industrialization. For Nigeria to drive its industrialization, electricity supply problem should be solved. Based on the empirical results, the following are recommended. Government expenditure should be streamlined in ways that attune it to the growth of the industrial sector. Targeting specific industrial concerns like textiles which employ a sizeable number of persons is germane and monetary policies such as appropriate exchange rate policies are called for.

Transfer of technology via foreign direct investment does not appear to have yielded the expected dividends. While the development of local technologies is germane, it may not be feasible to forgo foreign technology. Adapting foreign technology to local conditions is vital. Since innovation can be embodied in technologies, the expectation is that technological changes through innovation as captured by foreign direct investment in the form of capital goods imports can drive industrial growth and this can be encouraged. Above all, the quality of service delivery is critical to the drive for industrialization in Nigeria. Specifically, the level of electricity consumption (through improved production) should be addressed and where required reforms instituted to make its production, distribution and transmission more efficient. This is likely to contain the huge costs associated with running industrial plants and power generators, and improve the level of output. Based on the results obtained from the investigation, it is essential to examine in future studies the contributions of other dimensions of institutions as key drivers of industrialization. Specifically, studies which link Nigeria's industrialization quest to other institutional variables are likely to bring to light interesting results. Consequently, future investigations could centre on variables such as governance, property rights, democratic accountability, civil liberties, empowerment rights, freedom of association, democracy, political rights, and women's political, economic and social rights, which are capable of shedding light on the policyindustrialization- institutions nexus. 


\section{References}

Adenikinju, A. (2005). Analysis of the Cost of Infrastructure Failure in a Developing Economy: The Case of Electricity sector in Nigeria. AERC Research Paper, 148, 1-44.

Agba, A. V. (2004). Long term funding options for manufacturing industries in Nigeria. A paper presented at 45th Annual conference of the Nigerian Economic Society, Abuja.

Aluko, M. A., Akinola, G. O. \& Fatakun, S. (2004). Globalization and the Manufacturing Sector: a Study of Some Selected Textiles Firms in Nigeria. Journal of Social Science, 9(2), 122-127.

Bakare, A. S. (2013). Investment Climate and the Performances of Industrial Sector in Nigeria. International Journal of Academic Research in Business and Social Sciences, 3(10), 11-21.

Blejer, M. I. \& Khan, M. S. (1984). Government policy and private investment in developing countries. IMF Staff Papers, 31(2).

Central Bank of Nigeria. (2014). Statistical Bulletin. Central Bank of Nigeria (CBN), Abuja, Nigeria.

Chukwuma, A. \& Aldo, C. (2013). Economic Diversification and Macroeconomic Policies: Re-Examining the Missing Link in Africa's Industrialization Strategies. A conference paper presented at UNU-WIDER's conference, held in Helsinki on 24-25, June.

Cimoli, M. \& Katz, J. (2003). Technological asymmetries and growth in Latin America. MPRA Paper 3832.

Ebong, F., Udoh, E. \& Obafemi, F. (2014). Globalization and the Industrial Development of Nigeria: Evidence from Time Series Analysis. International Review of Social Sciences and Humanities, 6(2), 12-24.

Fischer, S. (1993). The Role of Macroeconomic Factors in Growth. Journal of Monetary Economics, 32(3), 485512.

Freeman, C. (1976). The Economics of Industrial Innovation, London: Penguin Books.

García-Belenguer, F. \& Santos, M. S. (2013). Investment rates and the Aggregate Production Function. European Economic Review, 63, 150-169.

Greene, J. \& Villanueva, D. (1991). Private Investment in Developing Countries: An Empirical Analysis. IMF Staff Papers 38.

Hendry, D. F. (1986). Econometric Modeling with Cointegrated Variables: An Overview. Oxford Bulletin of Economics and Statistics (August), 201-212.

International Monetary Fund. (2010). Global Trade Liberalization and the Developing Countries. IMF Issue Brief, November.

Johansen, S., Mosconi, R. \& Nielsen, B. (2000). Cointegration analysis in the presence of structural breaks in the deterministic trend. Econometrics Journal, 3, 216-249.

Michael, A. A. \& Babasanmi, B. O. (2004). Institutional Framework, Interest Rate Policy and the Financing of the Nigerian Manufacturing Sub-Sector. Africa Development and Poverty Reduction: The MacroMicro Linkage Forum Paper, 2004 Lord Charles Hotel, Somerset West, South Africa 13-15 October, 236.

Mordi, N. O. C., Abwaku, E. \& Banji, S. A. (2010). The Changing Structure of the Nigerian Economy. The Research Department, Central Bank of Nigeria, 257-262.

Ndebbio, J. E. U. (2006). The Structural Economic Dimensions of Underdevelopment, Associated Vicissitudes and Imperatives: Agenda for Positive Change. Saesprint Publishers, Nigeria.

Ndiyo N. A. \& Ebong, E. B. (2003). The challenges of openness in developing economies: Some empirical lessons from Nigeria. Paper presented at the 2003 Annual Conference of the Nigerian Economic Society.

Odior, E. S. (2005). Macroeconomic Variables and the Productivity of the Manufacturing Sector in Nigeria: A Static Analysis Approach. Journal of Emerging Issues in Economics, Finance and Banking, 1(5), 362380.

Osabuohien, E. S., Beecroft, I., Uchenna, E. R. \& Oluwatobi, S. (2013). Does Everything Rise and Fall on Institutions? Sectoral Analysis of Socioeconomic Transformation in Nigeria. Paper Presented at the 54th Annual Conference of Nigerian Economic Society on Institutions, Institutional Reforms and Economic Development, 17-19th September, Shareton Hotels and Towers, Abuja.

Papageorgiou, C. \& Spatafora, N. (2012). Economic Diversification in LICs: Stylized Facts and Macroeconomic Implications. IMF Staff Discussion Note, December 14. SDN/12/13.

Perron, P. (1989). The great crash, the oil price shock, and the unit root hypothesis. Econometrica, 57, 13611401. 
Perron, P. (1997). Further evidence on breaking trend functions in macroeconomic variables. Journal of Econometrics, 80, 355-385.

Prebisch, R. (1950). The Economic Development of Latin America and its Principal Problems. Reprinted in Economic Bulletin for Latin America, 7(1), 1962, 1-22.

Sen, A. (2003). On unit root tests when the alternative is a trend-break stationary process. Journal of Business and Economic Statistics, 21(1), 174-184.

Singer, H. W. (1950). U.S. Foreign Investment in Underdeveloped Areas: The Distribution of Gains between Investing and Borrowing Countries. American Economic Review, Papers and Proceedings, 40, 473-485.

Soderbom, M. \& Francis, T. (2002). The Performance of Nigerian Manufacturing Firms: Report on the Nigerian Manufacturing Enterprise Survey 2001. United Nations Industrial Development Organization and Centre for the Study of African Economies, University of Oxford, August.

Syrquin, M. (1986). Growth and Structural Change in Latin America since 1960: A Comparative Analysis. Economic Development and Cultural Change. University of Chicago Press, 34(3), 433-454.

Ubi, P. S., Lionel, E. \& Eyo, E. I. (2012). Monetary Policy and Industrialization in an Emerging Open Economy: Lessons from Nigeria. International Journal of Academic Research in Business and Social Sciences, 2(8), 270-288.

Udah, E. B. (2010). Industrial Development, Electricity Crisis and Economic Performance in Nigeria. European Journal of Economics, Finance and Administrative Sciences, 18, 105-121.

Umo, J. U. (2012). Escaping Poverty in Africa: A Perspective on Strategic Agenda for Nigeria. Millennium Text Publishers Ltd., Lagos, p. 34.

United Nations Economic Commission for Africa (UNECA). (2012). Economic Transformation for Africa's Development. UNECA Macroeconomic policy Division, C-10 Meeting April. Washington DC.

Weder, B. (1998). Africa's Trade Gap: What Should Africa do to Promote Exports. Paper presented at the Workshop on Asia and Africa in the Global Economy, August 1998, United Nations University, Tokyo, Japan.

World Bank. (2012). World Development Report, Washington, DC: World Bank

World Bank. (2013). World Development Report, Washington, DC: World Bank

World Bank. (2014). World Development Indicators. The World Bank, Washington DC.

Zivot, E. \& Andrews, D. (1992). Further Evidence of the Great Crash, the Oil-Price and the Unit-Root Hypothesis. Journal of Business and Economics Statistics, 10, 251-270.

\section{APPENDIX}

Table 1A: Descriptive Statistics

\begin{tabular}{llllll}
\hline & IND & GE & REXCR & TECTRANS & QSERVDEL \\
\hline Mean & 1.679471 & 2.198462 & 4.920526 & 0.928236 & 4.261795 \\
Median & 1.703875 & 2.121373 & 5.094904 & 0.992333 & 4.491085 \\
Maximum & 2.345383 & 2.887247 & 5.633657 & 2.382556 & 5.003466 \\
Minimum & 0.879681 & 1.575519 & 3.856702 & -0.409899 & 0.000000 \\
Std. Dev. & 0.455746 & 0.370784 & 0.571223 & 0.675778 & 1.123612 \\
Skewness & -0.308792 & 0.082732 & -0.638715 & -0.024395 & -3.417692 \\
Kurtosis & 1.981285 & 1.873707 & 2.022830 & 2.645281 & 13.36450 \\
Jarque-Bera & 1.951387 & 1.781883 & 3.556699 & 0.176283 & 211.9499 \\
Probability & 0.376931 & 0.410269 & 0.168917 & 0.915631 & 0.000000 \\
Sum & 55.42255 & 72.54926 & 162.3774 & 30.63177 & 140.6392 \\
Sum Sq. Dev. & 6.646533 & 4.399388 & 10.44145 & 14.61364 & 40.40016 \\
Observations & 33 & 33 & 33 & 33 & 33 \\
& & & & & \\
Correlation matrix & 1.00000 & 0.32628 & -0.55736 & -0.57107 & -0.35599 \\
IND & 0.32628 & 1.00000 & -0.77411 & -0.21143 & 0.01203 \\
GE & -0.55736 & -0.77411 & 1.00000 & 0.46689 & 0.11876 \\
REXCR & -0.57107 & -0.21143 & 0.46689 & 1.00000 & 0.33441 \\
TECTRANS & -0.35599 & 0.01203 & 0.11876 & 0.33441 & 1.00000 \\
QSERVDEL & & & & &
\end{tabular}

Source: Authors' computations 
Table 1B: Unit Root Test Results (with constant and trend)

\begin{tabular}{llll}
\hline & ADF & PP & KPSS \\
\hline IND & -0.329134 & -0.487851 & $0.209208^{* *}$ \\
GE & -2.491227 & -2.572480 & 0.077676 \\
REXCR & -2.550142 & -2.124716 & $0.148428^{* *}$ \\
QESERVDEL & -1.357975 & -2.435772 & $0.294468^{*}$ \\
$\Delta$ IND & -1.870415 & $-3.353003^{* * *}$ & $0.175913^{* *}$ \\
$\Delta$ GE & $-4.239956^{* *}$ & $-5.974215^{*}$ & 0.110225 \\
$\Delta$ REXCR & $-4.319710^{*}$ & $-6.200062^{*}$ & 0.051377 \\
$\Delta$ TECTRANS & $-3.611104^{* *}$ & $-4.467072^{*}$ & 0.045807 \\
$\Delta$ QSERVDEL & $-4.742339^{*}$ & $-10.30152^{*}$ & 0.044867 \\
\hline
\end{tabular}

*,** and ${ }^{* * *}$ indicate statistical significance at the $1 \%, 5 \%$ and $10 \%$ levels respectively. Maximum lag used is 1.

Source: Authors' computations.

Table 1C Unit root (with structural breaks) test results

Panel A: Test with a structural break in the intercept (Model A)

\begin{tabular}{|c|c|c|c|c|c|c|}
\hline \multirow[b]{2}{*}{ Variable } & \multicolumn{3}{|c|}{ Zivot-Andrews } & \multicolumn{3}{|l|}{ Perron } \\
\hline & t-statistics & $\begin{array}{l}\text { Break } \\
\text { date }\end{array}$ & $\begin{array}{l}\text { Maximum } \\
\text { lag }\end{array}$ & t-statistics & $\begin{array}{l}\text { Break } \\
\text { date }\end{array}$ & $\begin{array}{l}\text { Maximum } \\
\text { lag }\end{array}$ \\
\hline IND & -1.84 & 2008 & 1 & -3.01 & 2008 & 1 \\
\hline GE & -3.21 & 1987 & 1 & -3.16 & 1986 & 1 \\
\hline REXCR & -3.10 & 1989 & 7 & -2.57 & 1986 & 1 \\
\hline TECTRANS & -2.63 & 1989 & 1 & -2.65 & 1988 & 1 \\
\hline QSERVDEL & $-5.01^{* * *}$ & 2004 & 1 & $-5.07^{* * *}$ & 2003 & 1 \\
\hline
\end{tabular}

Note: ${ }^{*}$ and ${ }^{* * *}$ denote significant at the 1 and 10 percent level. The asymptotic critical values of Perron Unit Root Test for model $\mathrm{A}$ at $1 \%, 5 \%$ and $10 \%$ are $-5.92,-5.23$ and -4.92 respectively. The asymptotic critical values of Zivot-Andrews test for model A at $1 \%, 5 \%$ and $10 \%$ are $-5.34,-4.93$ and -4.58 respectively.

Panel B: Test with a structural break in the intercept and trend (Model C)

\begin{tabular}{|c|c|c|c|c|c|c|}
\hline \multirow[b]{2}{*}{ Variable } & \multicolumn{3}{|c|}{ Zivot-Andrews } & \multicolumn{3}{|l|}{ Perron } \\
\hline & t-statistics & $\begin{array}{l}\text { Break } \\
\text { date }\end{array}$ & $\begin{array}{l}\text { Maximum } \\
\text { lag }\end{array}$ & t-statistics & $\begin{array}{l}\text { Break } \\
\text { date }\end{array}$ & $\begin{array}{l}\text { Maximum } \\
\text { lag }\end{array}$ \\
\hline IND & $-5.17^{* *}$ & 2008 & 1 & -5.11 & 2007 & 1 \\
\hline GE & -3.73 & 1993 & 1 & -3.96 & 1993 & 1 \\
\hline REXCR & -3.46 & 1993 & 5 & -2.67 & 1993 & 1 \\
\hline TECTRANS & -3.36 & 1993 & 1 & -3.30 & 1992 & 1 \\
\hline QSERVDEL & $-5.48^{* *}$ & 2002 & 1 & $-5.49^{* * *}$ & 1996 & 1 \\
\hline
\end{tabular}

Note: ${ }^{*}$ and ${ }^{* * *}$ denote significant at the 1 and 10 percent level. The asymptotic critical values of Perron unit root test for model $\mathrm{C}$ at $1 \%, 5 \%$ and $10 \%$ are $-6.32,-5.59$ and -5.29 respectively. The asymptotic critical values of Zivot-Andrews test for model $\mathrm{C}$ at $1 \%, 5 \%$ and $10 \%$ are $-5.57,-5.08$ and -4.82 respectively.

Source: Author's computations. 
Table 1D: Johansen Cointegration Test

\begin{tabular}{lllll}
\hline Null & Alternative & LR Statistic & $\mathbf{9 5 \%}$ & $\mathbf{9 9 \%}$ \\
\hline$r=0$ & $r \geq 1$ & $198.14^{*}$ & 112.91 & 122.46 \\
$r \leq 1$ & $r \geq 2$ & $108.73^{*}$ & 83.69 & 92.05 \\
$r \leq 2$ & $r \geq 3$ & 54.51 & 58.41 & 65.59 \\
$r \leq 3$ & $r \geq 4$ & 31.01 & 36.84 & 42.79 \\
$r \leq 4$ & $r \geq 5$ & 10.01 & 18.66 & 23.21 \\
\hline
\end{tabular}

Note: ${ }^{*}$ indicates significant at 1\%. Optimal Endogenous Lags from Information Criteria: Akaike Info Criterion: 4; Final Prediction Error: 6; Hannan-Quinn Criterion: 4; Schwarz Criterion: 4.

Source: Authors' computations, using JMulti.

Table 1E: Causality Test Results

\begin{tabular}{llll}
\hline Null hypothesis & Test statistic & p-value & Conclusion \\
\hline IND $\nrightarrow$ GE, TECTRANS, QSERVDEL, REXCR & $33.4286^{*}$ & 0.0000 & Reject \\
GE $\nrightarrow$ TECTRANS, QSERVDEL, REXCR, IND & $11.1342^{*}$ & 0.0000 & Reject \\
TECTRANS $\nrightarrow$ GE, QSERVDEL, REXCR, IND & $3.7026^{*}$ & 0.0012 & Reject \\
QSERVDEL $\nrightarrow$ GE, TECTRANS, REXCR, IND & $15.8250^{*}$ & 0.0000 & Reject \\
REXCR $\rightarrow$ GE, TECTRANS, QSERVDEL, IND & $2.5880^{* *}$ & 0.0141 & Reject \\
\hline
\end{tabular}

Note: $\nrightarrow$ denotes "does not Granger-cause". * and ${ }^{* *}$ represent $1 \%$ and 5\% level of significance respectively. Source: Authors' computations, using JMulti.

Figure 1A: Trend of Variables
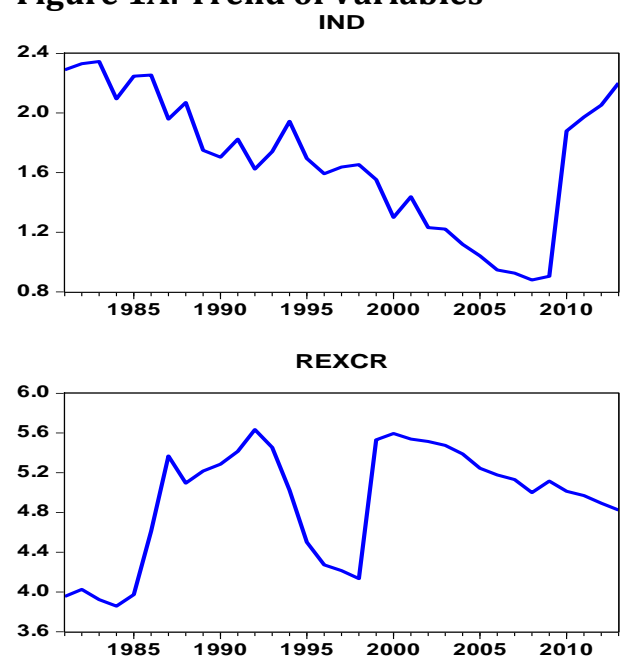

QSERVDEL

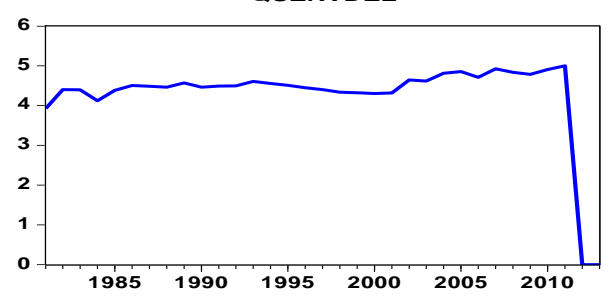

Source: Authors' computations.
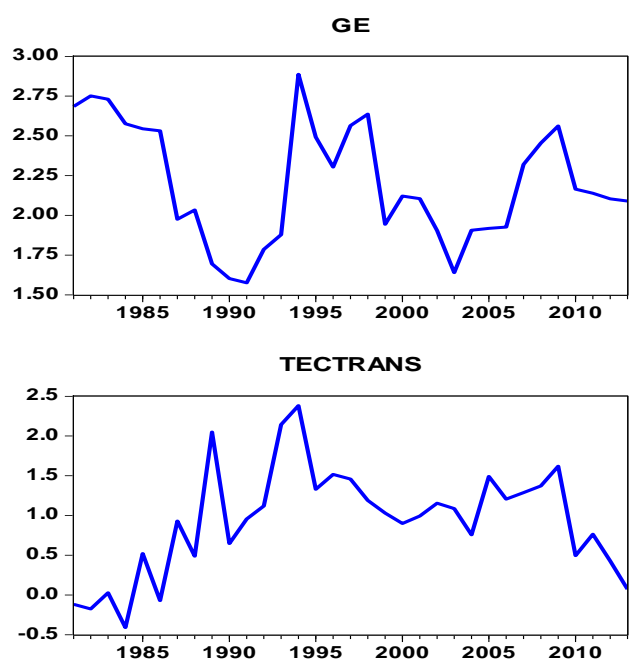